\title{
Strategic Entrepreneurial Dimensions of Rural Self Employed Women in Kerala: A Micro-Study
}

\section{OPEN ACCESS}

Manuscript ID:

ECO-2021-09044202

Volume: 9

Issue: 4

Month: September

Year: 2021

P-ISSN: 2319-961X

E-ISSN: 2582-0192

Received: 20.04.2021

Accepted: 30.07 .2021

Published: 01.09.2021

Citation:

Samuel, Liji. "Strategic Entrepreneurial Dimensions of Rural Self Employed Women in Kerala: A Micro-Study." Shanlax International Journal of Economics, vol. 9, no. 4, 2021, pp. 37-43.

\section{DOI:}

https://doi.org/10.34293/ economics.v9i4.4202

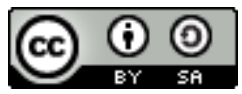

This work is licensed under a Creative Commons Attribution-ShareAlike 4.0 International License

\author{
Liji Samuel \\ Research Scholar, Department of Economics \\ University of Kerala, Kariavattom Campus, Trivandrum, Kerala, India \\ (D) https://orcid.org/0000-0001-9480-2298
}

\begin{abstract}
For the past 25 years, Indian women have taken a bold stance to overcome the illicit commercial world to this day. Women's business growth can be seen as a way to empower women. During the period of participation, women's participation in household income has increased. In India, women entrepreneurs face many challenges in starting their businesses. Earlier, women were reported to have more problems than other men in their families and discrimination against women.

Keywords: Women entrepreneur, Rural development, Tailoring, Self-Employed, Kollam, Kerala
\end{abstract}

\section{Introduction}

Human beings have been enterprising since the dawn of history. Entrepreneurs are individuals who initiate, organize, manage and control the activities of business units to supply goods and services. They provide the dynamic force in the economic life of society[Schumpeter, 1951]. The progress of the right kind of entrepreneurship is one of the experiments in an emerging country like India. The participation of women in income-generating activities for the family has been increasing over time. Female work participation not only increases their family income but also brings economic independence among women in the households.

\section{Functions of an Entrepreneur}

Modern writers on entrepreneurship outline broadly three functions of the entrepreneur: 1. Innovation 2. Risk-taking and 3. Organization and management of a business to have leadership and control over it[Nath, 2000]. A woman as an entrepreneur is economically more powerful than as a more worker because ownership not only confers regulators over assets (and liabilities) but also so gives her the freedom to create decisions. Through entrepreneurship development, women will not only generate income for themselves but also will create employment for other women in the locality[Biplab Moitra,2001]. This will have a multiplier effect on the generation of income and poverty alleviation.

\section{Women Entrepreneur}

In India, women's entrepreneurship can be considered as "necessity entrepreneurship" rather than "opportunity entrepreneurship" [Manimekalai, 1998]. Women usually have smaller networks and less geographical mobility than men, more so in young, married women who need to take care of their families. These women can use their skills and available local resources to start their enterprises[Nair,1998]. 
However, the location of the enterprise and the strength of the relationship with contact is essential as it determines the entrepreneur's ability to acquire and employ the resources available in her community [Vijaya Lekshmi, 2019].

In the Kerala context, the many difficulties involved in pursuing an entrepreneurial career and the difficulties faced by existing entrepreneurs demotivate and discourage the unemployed from taking up entrepreneurial jobs[Oommen,1981]. They prefer wage or salary employment to entrepreneurship. There is a mutual belief that 'all business is risky', and there is significant truth in this belief. The entrepreneur has to choose from among several imaginable alternatives in performing their task effectively. If their planning or estimation about the future were to go wrong, they would face problems.

\section{Field Study}

Most women are engaged in the unorganized sector like agriculture agro-based industries, handicrafts and Handloom and Cottage based industries. Table 1 discloses the rate of women in the participation of entrepreneur activities. In this context, an attempt was made to analyse the selfemployed women in Kollam and highlight their family background factors influencing to be selfemployed women, their income-generating activities and attitudes of women.

\section{Scope of the Study}

Women entrepreneurs in India face numerous problems in establishing as well as the successful running of their business. During the start-up phase, women are reported to encounter more problems than their male complements, both within their family and as part of the more extensive system which discriminates against women. in the scope of the stud is to appreciate the various factors accountable for being a self -employed women and for evaluating and examining the charges canvassing the customers and different method of doing venture by the self employed women in Kollam district.

\section{Objectives}

The field study has the following objectives

1. To access the factors responsible for being a selfemployed woman

2. To examine the method of doing venture by the self-employed women.

3. To examine the ways of fixing the charges by the self-employed women.

4. To evaluate the method of canvassing the customers by a self-employed women

\section{Methodology}

The researcher had collected the data from the self-employed women at Kollam. The selfemployed women considered are women who are doing tailoring jobs. They are doing this job during their leisure time .some women are doing tailoring jobs professionally. This study covers all types of women who are doing tailoring jobs. The researcher had prepared an interview schedule for this purpose, specifically by herself. The guide helps the researcher in preparing the interview schedule. The statistical method of the chi-square test is applied to know the significant relationship.

\section{Hypothesis}

The following null hypothesis has been prepared to find out the significant relationship.

1. There is no significant relationship between the period of doing business and specialist in tailoring

2. There is no significant relationship between the monthly income of the respondents and availing of loan by the respondents

\section{Results and Discussion}

The collected data have been analyzed in the following manner. The respondents' socio-economic background is also considered for analysis .from table 2 , and it can be observed that $71 \%$ of respondents are aged 35 years and in less .so it is evident that younger women are more into tailoring in Kollam .the. Table 3 that $39 \%$ of the respondents state their educational qualification to be below S.S.L.C. Only 22 percent of the respondents are graduates. Hence it may be inferred that because of fewer educations, women opt for tailoring promotion to earn primary additional income. 
From table 4 , it is clear that as many as $68 \%$ of the respondents stated to be married. It is evident from this that married respondents are responsible for maintaining the family for which they are into income-generating activities like tailoring jobs it is clear from Table 5 that 91 per cent of respondents have not employed any assistant. This indicates that only $9 \%$ of respondents can afford to hire an assistant while the other 91 percent do not find the need to hire assistants or cannot afford to hire an assistant.

From table 6, it is clear that 83 per cent of the respondents are not teaching that tailoring practices to anybody, indicating that many aims to bear only through tailoring. At the same time, few earn by tailoring and tailoring methods. Table 7 reveals that three per cent of the respondents have selected a tailoring job for additional income. In comparison, 29 per cent of the respondents have chosen it for helping their family .18\% stated to choose to tailor more for economic empowerment and opportunity exploitation than as a job.

From table 8 , it is clear that $34 \%$ of the respondents are homemakers and $30 \%$ of the respondents are students who could be supplementing with a family income through tailoring $.17 \%$ stated to be unemployed before taking up tailoring these women could have considered tailoring for self-employment as a last resort. From table 9, it can be that as many as $54 \%$ of the respondents determine the charges for tailoring a job based on design, and 20 per cent of the respondents determine costs based on work involved in tailoring the job. Design and work involved thus are found to be the major factors considered to determine tailoring charges.

The above observation reveals that $61 \%$ of the respondents use their tailoring income to meet family expenses. Indicating that over 60 per cent have taken up tailoring to supplement the family income from table 11 , it is clear that 90 per cent of the respondents have not received any advance from the customers, indicating that generally, charges are required to be paid only after the completion of the work.
Table 1 Participation of Women in Entrepreneurial Activities

\begin{tabular}{|l|c|}
\hline $\begin{array}{c}\text { Participation of Women in Entrepreneurial } \\
\text { Activities }\end{array}$ & $\%$ \\
\hline Women in the total population & 49.7 \\
\hline Women in a total workforce & 36.4 \\
\hline Women in total unemployed & 40.0 \\
\hline Women in total self-employed & 5.2 \\
\hline Women in total S.S.I. entrepreneurs & 6.2 \\
\hline
\end{tabular}

Source: Social welfare, May 2016

Table 2 Age Group of the Respondents

\begin{tabular}{|c|c|c|}
\hline Age Group (years) & No.of respondents & $\%$ \\
\hline Below -25 & 24 & 49 \\
\hline $25-35$ & 15 & 22 \\
\hline $35-45$ & 16 & 23 \\
\hline Above 45 & 4 & 6 \\
\hline Total & 59 & 100 \\
\hline
\end{tabular}

Table 3 Educational Qualification of The Respondents

\begin{tabular}{|l|c|c|}
\hline $\begin{array}{c}\text { Educational } \\
\text { Qualification }\end{array}$ & No. of Respondents & $\mathbf{\%}$ \\
\hline Below S.S.L.C. & 17 & 39 \\
\hline S.S.L.C. & 17 & 25 \\
\hline $\begin{array}{l}\text { Higher } \\
\text { secondary }\end{array}$ & 10 & 14 \\
\hline Graduation & 22 & -- \\
\hline \multicolumn{1}{|c|}{ Total } & 59 & 100 \\
\hline
\end{tabular}

Table 4 Marital Status of The Respondents

\begin{tabular}{|l|c|c|}
\hline Marital Status & No. of Respondents & $\mathbf{\%}$ \\
\hline Married & 37 & 68 \\
\hline Unmarried & 22 & 32 \\
\hline Total & 59 & 100 \\
\hline
\end{tabular}

Table 5 Assistant employed by The Respondents

\begin{tabular}{|l|c|c|}
\hline Assistant Employed & No. of Respondents & $\mathbf{\%}$ \\
\hline Employed & 6 & 9 \\
\hline Not employed & 53 & 91 \\
\hline Total & 59 & 100 \\
\hline
\end{tabular}


Table 6 Teaching of tailoring done by the Respondents

\begin{tabular}{|l|c|c|}
\hline Teaching of Tailoring & No. of Respondents & $\mathbf{\%}$ \\
\hline Teach & 12 & 17 \\
\hline Do not teach & 47 & 83 \\
\hline Total & 59 & 100 \\
\hline
\end{tabular}

Table 7 Reasons for Selecting the Tailoring Job

\begin{tabular}{|l|c|c|}
\hline \multicolumn{1}{|c|}{ Reasons } & No.of Respondents & $\mathbf{\%}$ \\
\hline hereditary & 7 & 10 \\
\hline $\begin{array}{l}\text { Additional } \\
\text { income }\end{array}$ & 20 & 43 \\
\hline $\begin{array}{l}\text { Economic } \\
\text { empowerment }\end{array}$ & 6 & 9 \\
\hline $\begin{array}{l}\text { Helping the } \\
\text { family }\end{array}$ & 20 & 29 \\
\hline $\begin{array}{l}\text { Utilize the } \\
\text { opportunity }\end{array}$ & 6 & 9 \\
\hline \multicolumn{1}{|c|}{ Total } & 59 & 100 \\
\hline
\end{tabular}

Table 8 Previous Experience of the Respondents

\begin{tabular}{|l|c|c|}
\hline \multicolumn{1}{|c|}{$\begin{array}{c}\text { Previous } \\
\text { Experience }\end{array}$} & No.of Respondents & $\mathbf{\%}$ \\
\hline Students & 11 & 30 \\
\hline Homemakers & 24 & 34 \\
\hline $\begin{array}{l}\text { Doing some } \\
\text { other business }\end{array}$ & 6 & 9 \\
\hline $\begin{array}{l}\text { From } \\
\text { childhood }\end{array}$ & 6 & 9 \\
\hline Unemployed & 12 & 17 \\
\hline \multicolumn{1}{|c|}{ Total } & 59 & 100 \\
\hline
\end{tabular}

Table 9 Basis for determining tailoring charges

\begin{tabular}{|l|c|c|}
\hline \multicolumn{1}{|c|}{ Basis } & No.of Respondents & \% \\
\hline Time & 4 & 6 \\
\hline Work & 14 & 20 \\
\hline Design & 27 & 54 \\
\hline Quality material & 3 & 4 \\
\hline Regular customer & 7 & 10 \\
\hline Urgent & 4 & 6 \\
\hline \multicolumn{1}{|c|}{ Total } & 59 & 100 \\
\hline
\end{tabular}

Table 10 Method of spending the tailoring income

\begin{tabular}{|l|c|c|}
\hline \multicolumn{1}{|c|}{$\begin{array}{c}\text { Method of } \\
\text { Spending }\end{array}$} & $\begin{array}{c}\text { No. of } \\
\text { Respondents }\end{array}$ & Percentage \\
\hline $\begin{array}{l}\text { Meet family } \\
\text { expenses }\end{array}$ & 32 & 61 \\
\hline $\begin{array}{l}\text { Meet personal } \\
\text { expenses }\end{array}$ & 14 & 20 \\
\hline Children study & 13 & 19 \\
\hline Total & 59 & 100 \\
\hline
\end{tabular}

Table 11 Advance received from the customers

\begin{tabular}{|c|c|c|}
\hline $\begin{array}{c}\text { Advance } \\
\text { Received }\end{array}$ & $\begin{array}{c}\text { No.of } \\
\text { Respondents }\end{array}$ & Percentage \\
\hline Received & 7 & 10 \\
\hline Not received & 52 & 90 \\
\hline Total & 59 & 100 \\
\hline
\end{tabular}

Table 12 Period of doing business and specialist in tailoring

\begin{tabular}{|c|c|c|c|}
\hline $\begin{array}{c}\text { Period } \\
\text { of Doing } \\
\text { Business } \\
\text { (Years) }\end{array}$ & Specialist & Not Specialist & Total \\
\cline { 2 - 3 } & 35 & 8 & 43 \\
\hline Up to 10 & 10 & 4 & 14 \\
\hline 10 to 20 & 8 & 5 & 12 \\
\hline 20 to 30 & 52 & 17 & 69 \\
\hline Total & & & \\
\hline
\end{tabular}

Source: primary data calculated value: 3.29

Table value at 5\% level of significance: 5.99

Table 13 monthly income and availing of loan

\begin{tabular}{|c|c|c|c|}
\hline $\begin{array}{c}\text { Monthly Income } \\
\text { of Rs. }\end{array}$ & \multicolumn{2}{|c|}{ Availing of Loan } & \multirow{2}{*}{ Total } \\
\cline { 2 - 3 } & yes & No & \\
\hline Up to 3000 & 5 & 9 & 14 \\
\hline 3001 to 5000 & 7 & 41 & 38 \\
\hline 5001 to 7000 & 3 & 4 & 7 \\
\hline Total & 15 & 54 & 59 \\
\hline
\end{tabular}

Source: primary data calculated value: 3.53

Table value at 5\% level of significance: 5.99

\section{Testing of Hypotheses}

The chi-square test has been applied to determine the significant relationship between doing business and specialists in tailoring. Table value at $5 \%$ level of significance: 5.99 


\section{Hypothesis}

There is no significant relationship between the period of doing business and specialists in tailoring.

\section{Inference}

The calculated value of chi-square is less than the table value. Hence, the hypothesis is accepted. It is concluded that there is no relationship between the period of doing business and specialists in tailoring. Respondents are not ready to get specialization in tailoring. The chi-square test has been applied to determine the significant relationship between monthly income and availing of loans by the respondents.

\section{Hypothesis}

There is no significant relationship between the monthly income of the respondents and availing of loans by the respondents.

\section{Inference}

The calculated value of chi-square is less than the table value. Hence, the hypothesis is accepted. It is concluded that there is no relationship between the monthly income of the respondents and availing of loans by the respondents. There is no need for a loan to do the tailoring job by the respondents.

\section{Conclusion}

This study examined women's entrepreneurship in the rural context of Kerala. It addressed the economic, social, educational and personal background of the entrepreneurs, the factors that motivated them to enter the field of entrepreneurship, and the different skills of these entrepreneurs. It has been observed that Kerala lacks business resources, but studies on entrepreneurship are few. The present study aims to fill some gaps in the research on entrepreneurship in Kerala. Generally, entrepreneurs who come from rural areas are not highly trained. They were also not very good at their academic performance, as evidenced by their S.S.L.C. scores. The scope of investment is small, except in exceptional cases.

In most cases, people become entrepreneurs at a relatively young age. Nevertheless, entrepreneurship was not the first profession in the case of the common of entrepreneurs. Entrepreneurs are primarily first- generation entrepreneurs, which means that they got into the business although their parents are not in the same field. However, it was observed that family members in a similar sector or their former personal experience in similar lines played a role in choosing the type of business[Wellington,2006]. It appears that the success or failure of the enterprise is instead a product of individual talents, which, as the outcomes indicate, are not necessarily shaped by the economic, personal, social and educational background of the entrepreneur. Since we are dealing with rural entrepreneurship, where most businesses can be categorized as minor, it is not shocking to find a relative similarity between businesses and entrepreneurs[ Delmar,2004]. It turns out that the differences that exist are not so essential to make variances in the units' performance.

According to the study, the presence of women in entrepreneurship is limited. It was noted that the entry of women was at a relatively late age. Businesses run by women have lower levels of investment compared to those run by men. The average investment of women entrepreneurs is about half of the businesses that are run by male entrepreneurs. Most women entrepreneurs run businesses that manufacture food products and ready-made clothing. The study found that a smaller percentage of women entrepreneurs were previously employed.

Nevertheless, women's entry into entrepreneurship is not driven by unfavorable conditions such as male unemployment. The study concluded that although women entrepreneurs slightly lack due to their background, they do slightly better than male entrepreneurs. Entrepreneurs have pointed out that external forces like market conditions, raw materials, competition, etc., play a central role in supporting or hindering business. It appears that in the case of these rural entrepreneurs, external forces play a more important role than their background in influencing business performance.

The current study sought to understand what motivates learners to start businesses versus the general job search pattern. Entrepreneurs were asked to identify the factors that motivated them. These motivating factors are broadly categorized as the most critical motives, motives/aspirations, compelling factors, facilitation and opportunities. 
In general, self-inspiration was the most critical factor motivating people to become entrepreneurs, whether they make a profit or not. This applies to both male and female entrepreneurs. This means that entrepreneurs themselves are the main drivers. They had the desire to start a business on their own.

It should be noted that women gave a high score to their husbands' motivation versus a low rating for men in this factor. This means that women's entry into this profession is supported and motivated by their husbands. When it comes to women's leadership, it is an important indicator. Government agencies played only a moderating role.

\section{References}

Aldrich, Howard. "Networking among Women Entrepreneurs." Women-Owned Businesses, edited by Oliver Hagan, et al., Praeger, 1989.

Beschäftigung nach Geschlecht, Alter und Stellung im Beruf (1 000). 2014b, https://ec.europa. eu/eurostat/de/web/products-datasets/ product? code $=$ lfsa_egaps.

Biplab, Moitra. "Women and Entrepreneurship." Kurushetra, vol. 49, no. 1, 2001, pp. 28-30.

Burns, Paul, and Jim Dewhurst. Small Business and Entrepreneurship. Macmillan, 1996.

Clain, Suzanne Heller. "Gender Differences in Full-Time Self-Employment." Journal of Economics and Business, vol. 52, no. 6, 2000, pp. 499-513.

Crompton, Rosemary, et al. Changing Forms of Employment. Routledge, 1997.

Delmar, Frederic, and Carin Holmquist. Women's Entrepreneurship: Issues and Policies. Organisation for Economic Cooperation and Development, 2004.

Edwin, Joel. "Entrepreneurship Creating Avenues." Yojana, vol. 52, 2015, pp. 39-41.

Estrin, Saul, and Tomasz Mickiewicz. "Institutions and Female Entrepreneurship." Small Business Economics, vol. 37, 2011.

Hagan, Oliver, et al. Women-Owned Businesses. Praeger, 1989.

Hesse-Biber, Sharlene Nagy. Feminist Research Practice - A Primer. Sage, 2014.

Kannan, Kamala. "The Role of Financial Institutions in Development of Women Enterprises."
Kurushetra, vol. 53, 2015.

Kirkwood, Jodyanne, and Beth Tootel. "Is Entrepreneurship the Answer to Achieving Work-family Balance?" Journal of Management \& Organization, vol. 13, no. 3, 2008, pp. 285-302.

Lekshmi, Vijaya. "Women Entrepreneurship and Finance." Social Welfare, vol. 49, no. 2, 2019.

Loscocco, Karyn A., et al. "Gender and Small Business Success: An Inquiry into Women's Relative Disadvantage." Social Forces, vol. 70, no. 1, 1991, pp. 65-85.

Manimekalai, N., and Mohammed Abdhullah. "Charcoal Production and Rural Entrepreneurship Development." Indian Economic Journal, vol. 45, no. 2, 1997.

Nair, K.B., et al. Rural Entrepreneurship in a Developing Economy: A Contingency Approach. 1998.

Nath, V. "Entrepreneurship by Regions and Castes." Economic and Political Weekly, vol. 35, 2000. Noseleit, Florian. "Female Self-Employment and Children." Small Business Economics, vol. 43, 2014, pp. 549-569.

Oommen, M.A. "Mobility of Small-Scale Entrepreneurs - Kerala Experiences.” Indian Journal of Industrial Relations, vol. 17, no. 1, 1981, pp. 65-87.

Rengarajan, L. Entrepreneurial Development. Sree Renga Publications, 2004.

Sappleton, Natalie. "Women Non-traditional Entrepreneurs and Social Capital." International Journal of Gender and Entrepreneurship, vol. 1, no. 3, 2009, pp. 192218.

Schumpeter, Joseph. The Theory of Economic Development. Harvard University Press, 1951.

Selbständigkeit Nach Geschlecht, Alter und Bildungsabschluss (1 000). 2014b, https:// ec.europa.eu/eurostat/de/web/productsdatasets/-/LFSQ ESGAED

Sharma, N.N. "A Comprehensive Framework for Evaluating Entrepreneurship Development Programmes." Paradigm, vol. 2, no. 1, 1998.

Thangamuthu, S., and S. Iyyampillai. "A Social Profile of Entrepreneurship.” Indian Economic 
Journal, vol. 31, 1985.

Tripathi, Dwijendra. "An Integrated View of Entrepreneurship." Economic and Political Weekly, vol. 20, no. 48, 1985.

Venkiteswaran, C.S. Entrepreneurs and their SocioCultural Background. University of Calicut, 1990.

Verheul, Ingrid, et al. "Explaining Preferences and Actual Involvement in Self-employment: Gender and the Entrepreneurial Personality.' Journal of Economic Psychology, vol. 33, no.
2, 2012, pp. 325-341.

Wellington, Alison J. "Self-employment: The New Solution for Balancing Family and Career?." Labour Economics, vol. 13, no. 3, 2006, pp. 357-386.

Xavier, Roland, et al. Global Entrepreneurship Monitor 2012 Global Report. 2012.

\section{Author Details}

Dr Liji Samuel, Research Scholar, Department of Economics, Kariavattom Campus, University of Kerala, Trivandrum, Kerala, India, Email ID: lijifridhu@gmail.com. 